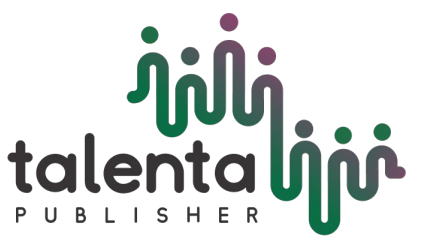

\title{
Isolation and Potential Testing of North Sumatera Berastagi Agricultural Soil In Degrading Marshal Insecticide With Carbosulfan Active Material
}

\author{
Nina Septania Damanik ${ }^{1}$, Nunuk Priyani ${ }^{2}$ and Erman Munir ${ }^{2}$ \\ ${ }^{1}$ Undergraduate student, Department of Biology, Fakulty of MIPA, Universitas Sumatera Utara, Jln. \\ Bioteknologi No. 1 Kampus USU, Padang Bulan, Medan 20155 \\ ${ }^{2}$ Department of Biology, Fakulty of MIPA, Universitas Sumatera Utara, Jln. Bioteknologi No.1, Kampus \\ USU, Padang Bulan, Medan 20155.
}

\begin{abstract}
The isolation of bacteria from Berastagi agricultural soil North Sumatera has been done. The aim is to evaluate their ability in degrading carbosulfan. Sixteen bacterial isolates were obtained using selective media Bushnel Hass Agar (BHA) containing 12 ppm of carbosulfan. The parameters observed were the growth of isolates, biosurfactant activity, biosurfactant concentration, and the residue of carbosulfan after 21 days of incubation. The result showed that all isolates were able to degrade carbosulfan as the sole carbon source. Two isolates namely JBM 3 (isolate from citrus agricultural soil Berastagi) and KBM 1 (isolate from cabbage agricultural soil Berastagi) were selected for further test to determine their ability to degrade carbosulfan. The results showed that both of the isolates were able to degrade carbosulfan. Compare to control, isolate JBM 3 was able to decrease the concentration of carbosulfan by $33.33 \%$, while isolate KBM 1 was able to reduce carbosulfan concentration up to $40.47 \%$.
\end{abstract}

Keyword: Carbosulfan, biodegradation of pesticide, bioremediation, biosurfactant

Received 11 June, 2020 | Revised 25 July, 2020 | Accepted 27 August, 2020

\section{Introduction}

Conventional agricultural products cannot be separated from the use of chemical pesticides . In agriculture, pesticides are a means to kill corpses of plant pests [1]. The use of pesticides has helped a lot to increase agricultural and plantation production. However, the use of these pesticides also has a negative impact on humans, biota and the environment [2].

Strengthening contamination of pesticides in the environment appear as continuous use of pesticides, ignore compliance in the use of dose, and the use of pesticides whose use outside official oversight [3]. Based on the type of pesticide, pesticides can undergo a biodegradation process, biologically changed in soil and water. However, there are some pesticides that cannot

*Corresponding author at: J. Bioteknologi No. 1 Kampus Univ. Sumatera Utara, Padang Bulan, Medan, Indonesia 
be biodegradable, these types are called persistent pesticides that can pollute the environment in very broad dimensions [4].

Chemical pesticides can be divided into several groups, namely organophosphates, carbamates, synthetic pyrethroids, and neonicotinoids which are broad-spectrum insecticides. Carbamate is an insecticide that has been widely used to control plant pests [5]. All carbamate insecticides have a carbamic acid base building block. In the decomposition environment, some carbamates produce metabolites that are still toxic [6], one of the active ingredients including carbamates is carbosulfan which works as a stomach poison. One of the insecticides that uses the active ingredient carbosulfan is Marshal 200 EC. This insecticide is very often used by farmers to kill insects.

Berastagi is the largest horticultural production center in North Sumatra, where its production cannot be separated from the use of various types of pesticides. The use of pesticides has been done by farmers for a long time, so that the microbes in the soil are able to use pesticide residues as a carbon source for their metabolic activities [3] .

The decomposition of pesticides in the environment can occur through microbial activity, chemical reactions, and sunlight which can occur at any time [2]. To overcome residual contamination from insecticides, the use of the role of degrading microbes can be a promising alternative for further study [3]. This paper reports the potential of the Berastagi agricultural soil bacterial isolates in degrading carbosulfan.

\section{Materials and Methods}

\section{Tools and Materials}

The tools used in this study include a centrifuge, shaker, a spectrophotometer and a ZB-1 CP3800 variant Gas Chromatography $(30 \mathrm{~m} \times 0.25 \mathrm{~mm} \times 0.25 \mu \mathrm{m})$ with an ECD detector. The materials used include samples of Berastagi agricultural land, insecticide with active ingredient carbosulfan with the trademark Marshal (200 EC), bushnell media - haas broth (BHB), bushnell - haas agar (BHA) (consisting of $\mathrm{KH}_{2} \mathrm{PO}_{4}, \mathrm{~K}_{2} \mathrm{HPO}_{4}, \mathrm{NH}_{4} \mathrm{NO}_{3}, \mathrm{MgSO}_{4} .7 \mathrm{H}_{2} \mathrm{O}, \mathrm{FeCl}_{3}$, $\mathrm{CaCl}_{2} .2 \mathrm{H}_{2} \mathrm{O}$, agar), $\mathrm{H}_{2} \mathrm{SO}_{4}$, o rsinol, rhamnose, diethyleter, tripton soy agar (TSA), plate count agar (PCA), Mc-Farland standard solution, distilled water, N-hexane, $0.05 \mathrm{M}$ sodium bicarbonate $\left(\mathrm{NaHCO}_{3}\right)$, dichloromethane, isoocan, toluene and $70 \%$ alcohol.

\section{Isolation and Characterization of Agricultural Soil Bacteria in Berastagi, North Sumatra}

Soil samples were taken as much as $1 \mathrm{~kg}$ from Berastagi agricultural land which contained pesticides. Soil sampling was carried out at four agricultural locations (chilies, oranges, cabbage and tomatoes). Sample the sample is weighed with as much as 1 gram and diluted in $10 \mathrm{ml}$ of 
aquades sterile until 10-2, inoculated $0.1 \mathrm{ml}$ to the BHA media which has to contain $12 \mathrm{ppm}$ carbosulfan with trademark Marshal 200 EC. The samples that have been inoculated onto the media are incubated at $30^{\circ} \mathrm{C}$ for $10-15$ days. Colonies of growing isolates were purified on TSA media. Then characterization colony morphology, cell shape, Gram staining, and a biochemical test consisting of citric test, gelatin, catalase, hidrogen sulfide, citric and starch .

\section{Isolate Growth Measurement}

Growth isolates during the incubation period is done by growing the bacteria on BHB mineral medium containing $12 \mathrm{ppm}$ carbosulfan. A total of $2 \mathrm{ml}$ in okulum liquid bacterial isolates $\mathrm{s}$ Etara by turbidity of the solution Mc-Farland inoculated into $100 \mathrm{ml}$ of media in aseptic, incubated on shaker $(150 \mathrm{rpm})$ in dark conditions at a temperature of $30^{\circ} \mathrm{C}$ for 21 days. The growth of isolates was observed every 7 days, namely on the $0^{\text {th }}, 7^{\text {th }}, 14^{\text {th }}$ and $21^{\text {st }}$ day. The measurement of the number of cells was carried out using the Standard Plate Count method. A total of $1 \mathrm{ml}$ of culture media was diluted to a concentration of $10-7$, then inoculated into PCA media aseptically using the scatter plate method and incubated for 24 hours. The number of colonies that grow calculated by colony counter. To calculate the estimated number of cells, it can be calculated with the formula: Estimation of cell count $=$ colony count $x \frac{1}{\text { the dilution factor }}(\mathrm{CFU} / \mathrm{ml})$

\section{Biosurfactant Activity Screening}

Activities biosurfactant produced by bacteria used method Drop Test Collapsing modified [7]. Bacterial isolates were grown on BHB media plus $2 \%$ dextros. A total of $2 \mathrm{ml}$ of bacterial isolate liquid inoculum equivalent to the turbidity of the Mc-Farland solution $\left(\approx 10^{8}\right.$ cells $\left./ \mathrm{ml}\right)$ was inoculated into $100 \mathrm{ml}$ of media aseptically, incubated in a shaker (150 rpm) under dark conditions at $30^{\circ} \mathrm{C}$ for 15 days. After 15 days of incubation, each culture medium was filtered and the filtrate was taken. A total of $4 \mathrm{ml}$ of media filtrate was added to the test tube, plus $4 \mathrm{ml}$ of $\mathrm{N}$-hexane and $2 \mathrm{ml}$ of distilled water. It was vortexed for 10 seconds, let stand for 1 minute. The thickness of the emulsion formed is measured with a caliper. Then converted to volume.

\section{Determination of the Biosurfactant Standard Curve}

Biosurfactant standard curve determination was performed using pure rhamnose from Sigma Aldrich Company, United States. The solution rhamnose made with different concentrations $(0$ (blank), 10, 50, 100 and $200 \mathrm{ppm}$ ) dissolved in a solution of sodium bicarbonate $\left(\mathrm{NaHCO}_{3}\right)$ $0,05 \mathrm{M}$, then each inserted into a test tube $2 \mathrm{ml}$. The solution of rhamnose was added with 3.6 $\mathrm{ml}$ of orsinol solution, heated to a boil, cooled at room temperature for 15 minutes and the absorbance was measured using a spectrophotometer with a wavelength of $421 \mathrm{~nm}$. The regression equation of the standard rhamnosa curve was determined by the Least Square method. 


\section{Biosurfactant Production}

The bacteria were grown on BHB media containing carbosulfan as a carbon source. Liquid inoculum bacteria solution which is equivalent to Mc-Farland much as $2 \mathrm{ml}$ was inoculated into $100 \mathrm{ml}$ of media, incubated on a shaker $(150 \mathrm{rpm})$ with a dark conditions at a temperature of $30^{\circ} \mathrm{C}$ for 21 days. The resulting biosurfactant production was analyzed using the modified orsinol method [8]. Bacterial culture was centrifuged $(6000 \mathrm{rpm})$ for 10 minutes to separate bacteria from the culture medium. The supernatant was taken $4 \mathrm{ml}$ and extracted with $2 \mathrm{ml}$ of diethyl ether for 5 minutes, the extraction was repeated 3 times. The ether layer was taken, dried and redissolved in $2 \mathrm{ml}$ of $0.05 \mathrm{M}$ sodium bicarbonate $\left(\mathrm{NaHCO}_{3}\right)$ solution.Then the sample solution was vortexed and added with $3.6 \mathrm{ml}$ of orsinol solution, heated to boiling, cooled at room temperature for 15 minutes and analyzed for its absorbance. using a spectrophotometer with a wavelength of $421 \mathrm{~nm}$.

\section{Potential Test of Biosurfactant Producing Bacteria in Degrading Carbosulfan}

Potential test of biosurfactant-producing bacteria in degrading carbosulfan during the incubation period was carried out with bacterial isolates grown on BHB mineral media containing $12 \mathrm{ppm}$ carbosulfan. A total of $20 \mathrm{ml}$ of bacterial isolate liquid inoculum which is equivalent to the turbidity of the Mc-Farland solution was inoculated into $980 \mathrm{ml}$ of media aseptically, incubated in a shaker (150 rpm ) under dark conditions at $30^{\circ} \mathrm{C}$ for 21 days. A sample of $300 \mathrm{ml}$ was put in a separating funnel, $100 \mathrm{ml}$ of dichloromethane was added. The sample and dichloromethane were extracted to form two phases. The organic phase is collected in a round flask. To water, 50 $\mathrm{ml}$ of dichloromethane was added again. This cycle takes place twice. Next, evaporation is done until it is almost dry. Then isoocan: toluene (9:1) is added until the volume reaches $3 \mathrm{ml}$. Analyzed by using Gas Chromatography Variant CP-3800 ZB-1 column (30m x $0.25 \mathrm{~mm}$ x $0.25 \mu \mathrm{m}$ ) with ECD detector, column temperature $200-270^{\circ} \mathrm{C}$, detector temperature $300^{\circ} \mathrm{C}$, injector temperature $280^{\circ} \mathrm{C}$. The sample is injected as much as $1 \mu 1$, the area is obtained, converted into $\mathrm{mg} / \mathrm{kg}$.

\section{Result and Discussion}

\section{Agricultural Soil Bacteria in Berastagi, North Sumatra}

The isolation results obtained were 16 isolates of biosurfactant-producing bacteria grown on Bushnell - Hass Agar (BHA) medium containing 12 ppm carbosulfan (Marshal 200 EC) as a carbon source. The isolates obtained were 4 isolates from chili farming land (CBM 1, CBM 2, CBM 3 and CBM 4), 3 isolates from citrus farming land (JBM 1, JBM 2, and JBM 3), 5 isolates from cabbage farming (KBM). 1, KBM 2, KBM 3, KBM 4 and KBM 5), and 4 isolates 
from tomato farming (TBM 1, TBM 2, TBM 3, TBM 4 and TBM 5). These bacterial isolates have varied morphological and Gram characteristics.

The isolates obtained showed a circular colony of 6 isolates, 6 isolates irregular (irregular) and 4 isolates, where the edges of the colony were entire (flat) as many as 11 isolates, lobate (split) as many as 4 isolates and undulate (choppy) 1 isolate. Meanwhile, the colony elevation is flat. Colonies of bacteria are white, milky white, fluorescent and transparent. Bacteria acquired shaped cocci by 7 isolates, cocobaccil by 5 isolates and baccil by 4 isolates. The bacteria obtained were dominated by Gram negative bacteria as many as 15 isolates and 1 Gram positive isolate. Biochemical characterization showed that all isolates had different characteristics .

\section{Isolate Growth}

The bacterial isolates obtained from the isolates were regrown on BHA media and 10 isolates were selected based on their growth ability. Each isolate has a different growth (Figure 1) .

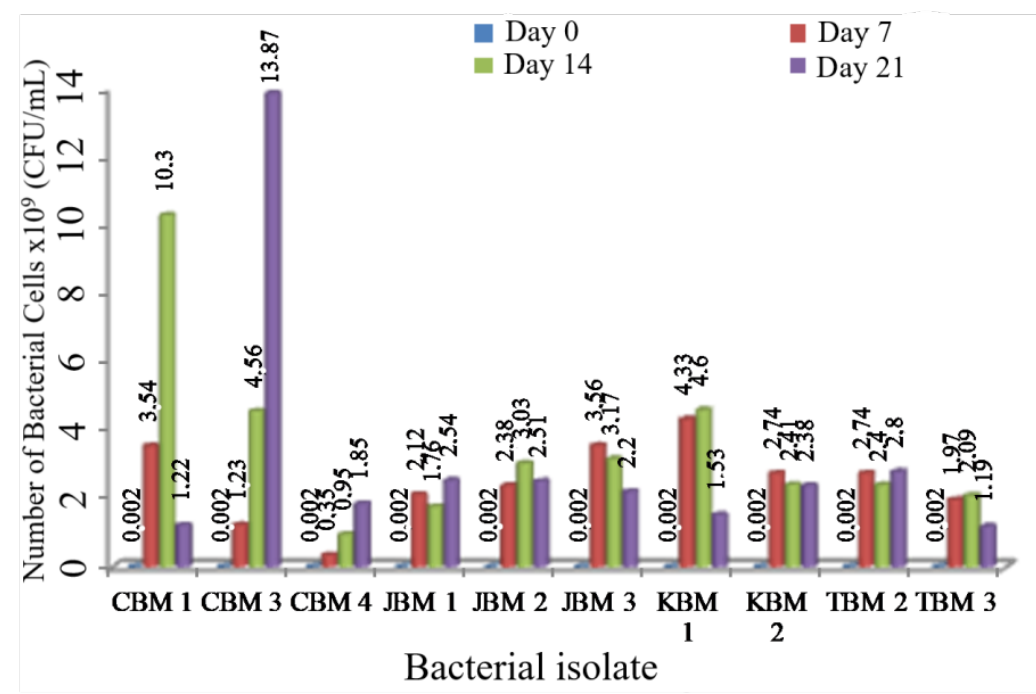

Figure 1. Growth of bacterial isolates during the culture period on BHB media containing carbosulfan

The growth rate of each bacterial isolate reached its optimum on day 14 and the growth of cell numbers decreased on day 21, however, some bacteria such as CBM 3, CBM 4, JBM 1 and TBM 2 experienced an increase in the number of cells on day 21 st. This is probably because each isolate has different growth phases, namely the adaptation period of each isolate to the available nutrients and the ability of each isolate to use carbosulfan or other compounds such as synthetic surfactants contained in the pesticide Marshal (200 EC) as carbon sources are also different, causing different growth rates in each bacterial isolate .

Lay [9], states that the difference in the growth rate of bacteria is caused by many factors, including the type and type of bacteria itself and the ability of these bacteria to use the nutrients available in the media for their metabolic processes. Hayatsu et al. [10] stated that bacteria 
isolated from soils contaminated with carbaryl (1-naphthyl N- methylcarbamate) were able to utilize carbaryl as the only carbon source. Carbaryl and carbosulfan are insecticides in the carbamate class which have the basic structure of carbamic acid in their structure.

Nasution [11] states that bacteria originating from the Tanjung Balai (TJB) are able to grow on media containing herbicides with active ingredients of glyphosate and use it as a source of carbon and energy. The growth of bacterial isolates reached $6.2 \times 10^{12} \mathrm{CFU} / \mathrm{ml}$ on the 6 th day. The level of carbosulfan toxicity based on its half-life is longer than glyphosate, which is likely to cause growth in media containing lower carbosulfan.

\section{Biosurfactant Activity Screening}

The biosurfactant activity was observed based on the volume of emulsion formed between the $\mathrm{N}$-hexane layer and the liquid media. The biosurfactant activity showed varied results as shown in Figure 2.

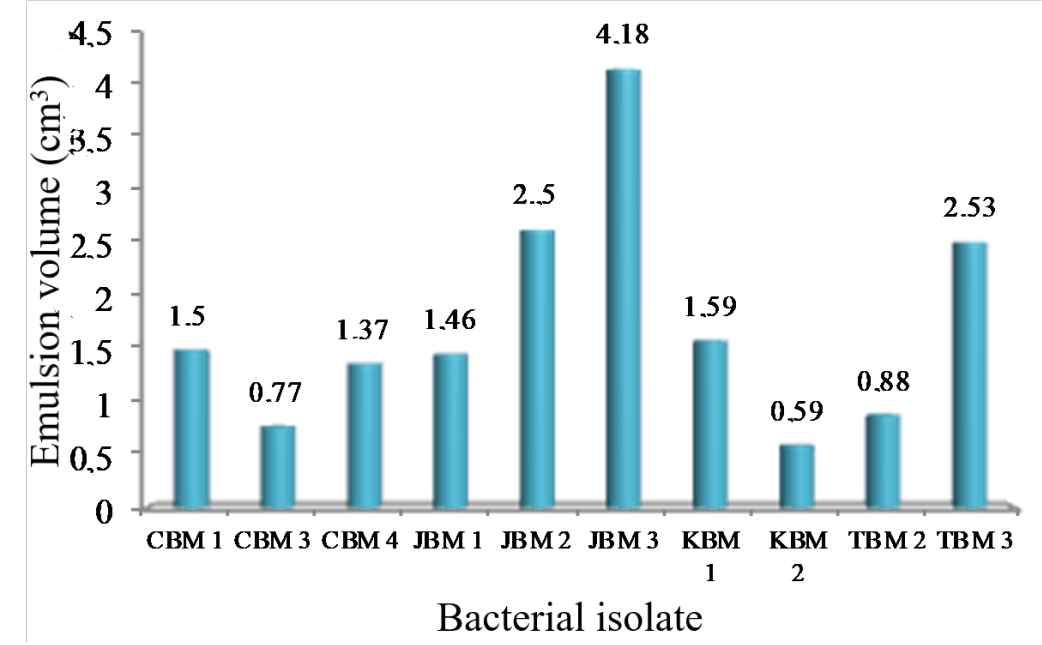

Figure 2. Biosurfactant activity of the Berastagi agricultural soil bacteria isolate

I solat JBM 3 had the highest emulsion activity with an activity value of $4.18 \mathrm{~cm} 3$ followed by isolates JBM 2, TBM 3 and KBM 1 with activity values of 2.65, 2.53 and 1,59 respectively. Meanwhile, the lowest emulsion activity was shown by the KBM 2 isolate, and it was not much different from the CBM 3 isolate with activity values respectively 0.59 and $0.77 \mathrm{~cm} 3$. I CBM 3 solate had the highest growth rate, while its biosurfactant activity had the lowest value compared to all tested isolates. This is probably due to the different components and types of biosurfactants produced .

Each isolate has a different biosurfactant activity which is indicated by the formation of an emulsion. According to Rosenberg et al., [12] the different types and components of biosurfactants produced by each isolate will affect the emulsion activity that occurs on the surface of the liquid. Warsito [13] states that the highest value of biosurfactant activity is shown by bacteria originating from the Tanjung Balai sea with a value of $13.50 \mathrm{~mm}$ grown on BHB 
media containing naphthalene (a hydrocarbon compound). The biosurfactant activity of the Berastagi agricultural soil bacteria in this study was higher when compared to bacteria originating from the Tanjung Balai sea.

According to Pacwa-Płociniczak et al . [14] the main characteristic of biosurfactants is that they have hydrophilic and hydrophobic parts, with these parts making it easier for bacteria to dissolve substances that are insoluble in water. The surfactant activity makes the surfactant a good emulsifying agent. Kosaric [15] states that emulsification of biosurfactants can occur due to several factors. Among them are the presence of hydrophobic and hydrophilic compounds, water conditions (salinity and $\mathrm{pH}$ ), temperature and components or the biosurfactant molecule itself.

\section{Biosurfactant Production}

The production of biosurfactants from each bacterial isolate has varying amounts as can be seen in Figure 3.

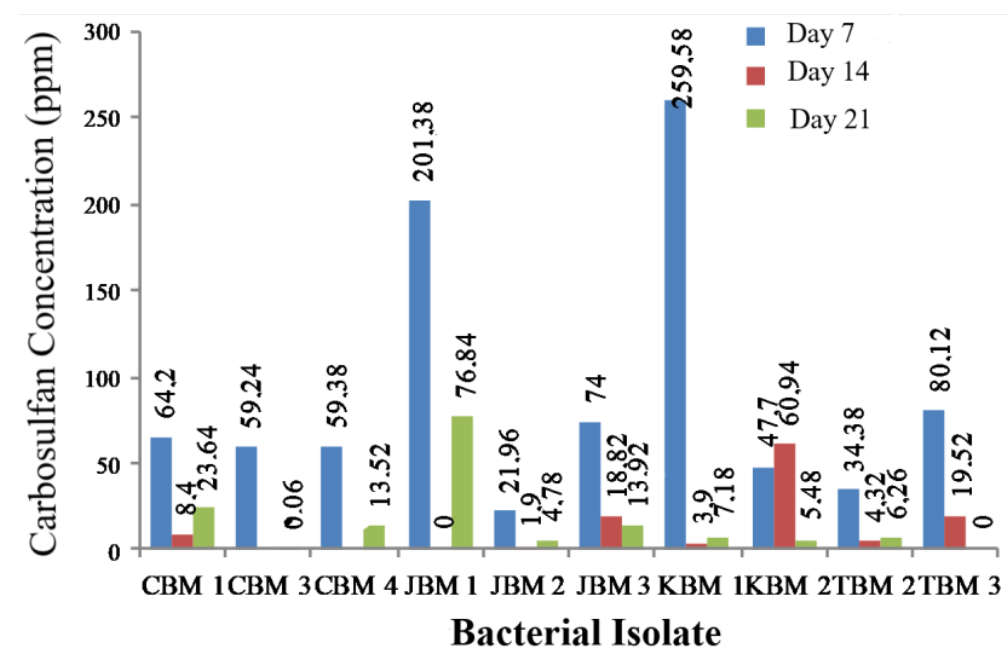

Figure 3. Production of bacterial isolate biosurfactants

The highest biosurfactant production of each isolate occurred on day 7 and biosurfactant production decreased on day 14 and day 21 . The highest concentration of biosurfactant was produced by bacterial isolates of KBM 1, JBM 1 , TBM 3 and JBM 3 respectively. From the results of cell growth measurements (Figure 1) and screening of biosurfactant activity (Figure 2) the KBM 1 isolate had a high enough cell number and biosurfactant activity, JBM 1 had a lower number of cells and biosurfactant activity than KBM 1, TBM 3 had biosurfactant production which was higher than JBM 3 but the cell growth and biosurfactant activity of TBM 3 was lower, while JBM 3 had a fairly high number of cells and the highest biosurfactant activity among all isolates. The high growth of bacterial isolates at the beginning of growth (day 7) can be associated with high biosurfactant production, where the high production of biosurfactants will help in the process of degradation of carbosulfan which is used as a carbon source. The presence of biosurfactants will increase the solubility of carbosulfan thereby increasing its 
availability to be degraded by bacteria. Likewise, the high biosurfactant activity of bacterial isolates can be associated with high biosurfactant production as well. On the 14th day the production of biosurfactants decreased significantly, but the growth had increased and also decreased, this was probably due to bacterial isolates preferring to use other carbon sources such as synthetic surfactants found in pesticides.

The difference in bacterial growth is thought to occur due to differences in the production of biosurfactants produced by bacteria. Biosurfactants play a role in emulsion formation so that hydrocarbon compounds become available as a carbon source in multiplying cell density in the test media. Li \& Chen [16] positive effect of surfactants on the degradation of hydrocarbons is associated with increased solubility and dissolution of hydrocarbon compounds. According to Batubara [17], the amount of biosurfactant produced also depends on how these microorganisms use the available nutrients. The difference in nutrition will affect the production of biosurfactants.

\section{Potential of Biosurfactant Producing Bacteria in Degrading Carbosulfan}

Test potential biosurfactant producing bacteria in degrading carbosulfan conducted by selecting two isolates based on the pattern of growth, activity and concentration biosurfactant biosurfactant is JBM 3 and MBC 1. Both isolates had the ability to lower the concentration of tar carbosulfan as seen in Figure 4 below.

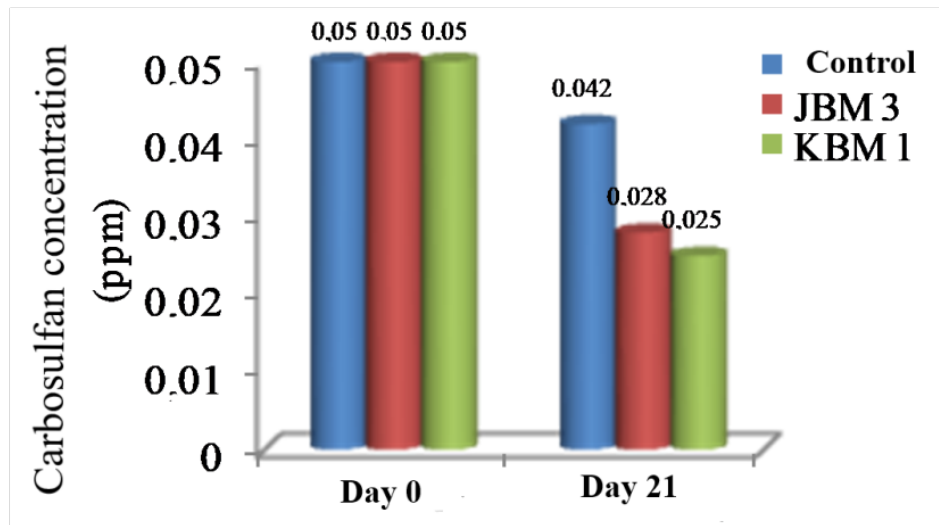

Figure 4. The remaining carbosulfan concentration of degradation on the $21^{\text {st }}$ day

Isolat bacteria JBM 3 and KBM 1 were able to reduce the carbosulfan concentration on the 21 st day. This shows that the two isolates are able to use carbosulfan as a carbon source which is indicated by a decrease in the concentration of carbosulfan. The decrease in carbosulfan concentration also occurred in the control treatment and bacterial isolate treatment. When compared with the control treatment, isolate JBM 3 was able to reduce the carbosulfan concentration by $33.33 \%$ (residual carbosulfan $0.028 \mathrm{ppm}$ ), while the KBM 1 bacterial isolate was able to reduce the carbosulfan concentration by $40.47 \%$ (residual carbosulfan $0.025 \mathrm{ppm}$ ) . The decrease in the concentration of carbosulfan in the control treatment was probably due to 
the fact that carbosulfan could be degraded naturally, such as through light. Katagi [18] states that photodegradation by sunlight is one of the destroyers of pesticides after being applied to the environment. Degradation due to sunlight is influenced by the intensity, spectrum of sunlight, duration of exposure and the nature of pesticides.

The ability of the JBM 3 and KBM 1 bacterial isolates to reduce the carbosulfan concentration after 21 days of incubation showed that the bacterial isolates were able to use carbosulfan as a carbon source. Suherman [19], bioremediation of diazinon organophosphate pesticides using indigenous microbes from rice fields showed a decrease in the concentration of diazinon after incubation for 27 hours, namely $55.52 \%$ initial concentration of $50 \mathrm{ppm}$. Based on its half-life, carbosulfan is longer when compared to diazinon, this is likely to cause a lower carbosulfan reduction. Andreu \& Pico [20], the degradation time of carbofuran (carbamate group) reaches 117 days, while diaz in on (organophosphate group) reaches 40 days. The ability of bacteria to use carbosulfan in this study was also supported by cell growth (Figure 1), surfactant activity (Figure 2) and high biosurfactant production (Figure 4) from bacterial isolates.

\section{Conclusion}

Isolate JBM 3 was able to decrease the concentration of carbosulfan by $33.33 \%$, while isolate KBM 1 was able to reduce carbosulfan concentration up to $40.47 \%$. .

\section{Acknowledgement}

The authors are thankful to the ministry of education for providing fund through Lembaga Penelitian, Universitas Sumatera Utara 2011/2012.

\section{REFERENCES}

[1] Yuantari, MGC. Environmental Economic Study of Pesticide Use and Its Impact on Farmers' Health in the Horticultural Agricultural Area of Sumber Rejo Village, Ngablak District, Magelang Regency, Central Java . [Thesis] . Semarang: Diponegoro University. 2009.

[2] Manuaba, IBP. Contamination of Carbamate Pesticides in Lake Buyan Buleleng Bali. J . Chemistry 3 (1) : 47-54. 2009.

[3] Rahmansyah, M., N, Sulistinah. Performance of Bacteria on Pesticide Contaminated Soil. Biology News 9 (5) : 657-664. 2009.

[4] Djafaruddin. Basics of Plant Disease Control. PT. Earth Literacy. Jakarta. 2008.

[5] Ak'yunin, K. Toxicity of several classes of insecticides against the mortality of Selenothrips rubrocinctus (Giard) in Jatropha curcas (Jatropha curcas L.) . [Thesis] . Malang: Islamic State University of Malang. 2008.

[6] Chapalamadugu, S., GR Chaudhry. Microbiological and Biotechnological Aspects of Metabolism of Carbamates and Organophosphates. Crit Rev Biotechnol. 12 (5): 357-389. 1992. 
[7] Jain, DK, DLC Thompson, H. Lee, JT Trevois. A Drop Collapsing Test for Screening Surfactant Producing Microorganisms. Microbial Method. 13 : 271-279. 1991.

[8] Koch, AK, O. Kappeli, A. Fiecher, J. Reiser. Hydrocarbon Assimilation and Biosurfactant Production in Pseodomonas aure ginosa Mutant. J. Bact. 173: 4212-4219. 1991.

[9] Lay, BW. Microbial Analysis in the Laboratory . PT. Raja Gr afindo Persada. Jakarta. 1994.

[10] Hayatsu, M., M. Hirano , T. Nagata. Involvement of Two Plasmids in the Degradation of Carbaryl by Arthrobacter sp. RC100 strain. Appl Environ Microbiol . 65 (3): 1015-1019. 1999.

[11] Nasution, N. Potential of Biosurfactant Producing Bacteria Isolates from Tanjung Balai Sea and North Sumatra Sibolga in Degradation of Glyphosate. [Thesis]. Medan: University of North Sumatra. 2011.

[12] Rosenberg, M., D. Gutnick, E. Rosenberg. Adherence of Bacteria to Hydrocarbons: A Simple Method for Measuring Cell-surface Hydrophobicity. FEMS Microbiol Lett . 9 : 29-33. 1980.

[13] Warsito, K. Isolation and Potential of Biosurfactant Producing Bacteria from the Sea of Sibolga and Tanjung Balai, North Sumatra in Degradation of Naphthalene . [ Thesis ] . Medan: University of North Sumatra. 2009.

[14] Pacwa-Płociniczak, M., G. A. Płaza, Z. Piotrowska-Seget, SS Cameotra. Environmental Applications of Biosurfactants: Recent Advances. I nt J. Mol Sci. 12: 633-654. 2011.

[15] Kosaric, N. Biosurfactants in Industry. Pure and Appl Chem. 64 : 1731-1737. 1992.

[16] Li Jing-Liang, Chen Bing-Hung. Surfactant-mediated Biodegradation of Polycyclic Aromatic Hydrocarbons. J . Materials 2: 76-94. 2009.

[17] Batubara, NR. Optimization of Biosurfactant Production by Pseudomonas aeruginosa with Variation of Carbon and Nitrogen Sources. [Thesis]. Medan: University of North Sumatra. 2011.

[18] Katagi, T. Photodegradation of Pesticides on Plant and Soil Surfaces. Rev Environ Contam Toxicol. 182: 1-195. 2004.

[19] Suherman, AD. Ex Situ Bioremediation of Organophosphate Types of Pesticide Residues Using Indigenous Microbes from Rice Fields. [Thesis] . Bogor: Bogor Agricultural University. 2000.

[20] Andreu, V., Y. Pico. Determination of pesticides and their degradation products in soil: critical review and comparison of methods. TrAC. 23 (10-11): 772-789. 2004. 